DOI: $10.14451 / 2.144 .11$

\title{
О ПРАВОВОМ ПОРЯДКЕ С СОВРЕМЕННЫХ ПОЗИЦИЙ
}

\author{
(C) 2020 Працко Г.С. \\ профессор кафедры гражданского и арбитражного процесса \\ Самарский государственный экономический университет, Россия, Самара \\ профессор кафедры «Коммерческое и предпринимательское право» \\ Донской государственный технический университет, Россия, Ростов-на-Дону \\ доктор философских наук, доктор юридических наук, профессор
}

В статье обосновывается идея о правовом порядке как явлении ценностном, имеющем место только при наличии демократического режима и основ гражданского общества и правовой государственности. В иных условиях устанавливается определенный порядок в социальной и правовой жизни, но он не обладает качествами порядка правового, поскольку не воспринимает ценности права и не обеспечивает должным образом естественные права и свободы личности.

Ключевые слова: правовой порядок, ценности права, система права, правовые законы, права и свободы личности, гражданское общество, правовое государство, демократический режим.

Наличие должного правового порядка важная особенность современной правовой действительности. Поэтому проблемы, связанные с наличием и действием правового порядка, сохраняют свою теоретическую и практическую актуальность.

По самой упрощенной схеме правопорядок представляется реализацией принципа законности. Но и к осмыслению принципа законности обнаруживается неоднозначный подход. Речь идет не просто о состоянии законности в значимых сферах социальной и правовой жизни общества, а о законности правовой по своей природе и сущности.

Практически сложилась концепция, констатирующая, что подлинной законности не может быть там, где господствуют тоталитарные, авторитарные и иные антидемократические режимы, отвергаются любые правовые ценности, отменяются, игнорируются, урезаются жизненно важные права и свободы человека, совершаются другие акции правового беспредела. Условная законность в таких условиях может быть лишь формальным обозначением некоего режима властвования, который соответствует интересам правящего меньшинства и противостоит жизненным притязаниям большинства членов общества.

Истинная законность может функционироватьлишь в тех государственных и общественных условиях, где она реально может квалифицироваться как законность правовая. Следовательно, реализация принципа, режима правовой закон- ности инициирует и установленный порядок в системе общественных отношений, который может быть представлен исключительно в качестве должного реального правового порядка.

Идеи, принципы, требования правовой законности могут воплощаться только в действительное состояние правового порядка. Поэтому вольное манипулирование категорией «правовой порядок» в качестве порядка, производного от термина «право» в современных условиях утрачивает такую сугубо формальную установку и не имеет достаточных оснований для полновесной квалификации. Это связано с тем обстоятельством, что под истинным правовым порядком подразумевается состояние правовой действительности достаточно емкое, сложное, значимое, ценностное, обладающее своей природой, сущностью, целевой направленностью и тесно связанное с общественным порядком, процессами и механизмами реализации прав и свобод человека.

Требуемый порядок в соответствующих областях государственной и общественной жизни может быть установлен усилиями любого государственно-политического режима, включая антидемократический режим. Но он не будет правовым по своей природе и сущности, если не будет обслуживать интересы и потребности подавляющей части членов общества, учитывать жизненные притязания отдельной личности. Любой порядок, не обусловленный ценностями права, функционирует лишь во благо определенных властно-элитарных кругов и структур и по- 
этому противостоит жизненным устремлениям значительной части населения, открыто игнорирует права и свободы человека.

Классическое определение правопорядка как порядка общественных отношений, складывающихся в результате соблюдения и исполнения законов и иных нормативно-правовых актов, как результата действия законности [1, с. 389] уводит от понимания этого правового явления с позиций правовых ценностей и наличия демократического режима. Твердый порядок, основанный на неукоснительном соблюдении действующих законов, может быть установлен и самым тоталитарным режимом.

Ситуация коренным образом может меняться только при наличии демократического политического режима, формировании основ гражданского общества и правового государства, резкого крена в сторону жизненных интересов и потребностей членов общества, признании личности, ее прав и свобод высшей социальной ценностью. Только устанавливаемый на этой основе порядок обретает качества правового порядка, пронизанного правовыми ценностями, отражающими самые естественные и сущностные жизненные притязания каждого человека.

В должном правовом порядке находит отражение такое функционирование структур государственной и муниципальной власти, которое в значительной мере соотносится с интересами и потребностями человека, целенаправленно поддерживает те деятельные акции, которые ведут к обретению личностью необходимых основ достойного существования.

Подлинный правовой порядок складывается параллельно с проявлением потенциала правовой законности. Должный порядок в системе общественных отношений достижим только тогда, когда все властные структуры государства, ответственные должностные лица не допускают никаких отклонений от юридических предписаний и требований и признают ценностное значение тех нормативно-правовых актов, прежде всего правовых законов, которые в первую очередь и непосредственно служат интересам членов развивающегося гражданского общества.

Порядок постепенно обретает свойства действительного правового порядка, когда находит понимание, признание и поддержку со стороны многочисленных институтов гражданского общества и членов этого общества.

Проявляясь в первую очередь в многогран- ной государственной сфере, правовой порядок расширяет диапазон своего действия и, в конечном счете, самым тесным образом соприкасается с общественным порядком, что увеличивает притягательную силу такого интегрированного порядка в лице значительной части членов общества. На базе такого надежного порядка каждая личность обретает возможность добиваться поставленных жизненных целей.

Укрепление правового порядка, повышение его эффективности требует, как и для внедрения правовой законности, волевых, решительных, целенаправленных усилий компетентных органов всех ветвей власти. Особая роль отводится законодательной власти, которая призвана издавать те законы, которые принято именовать в теории права правовыми законами. Предназначение таких законов, как известно, заключается в том, чтобы в приоритетном порядке обслуживать жизненные притязания членов гражданского общества. Аккумулируемые правовыми законами правовая законность и правовой порядок в решающей степени обусловливают общую ценностную правовую основу функционирования развивающихся гражданского общества и правового государства, сферу реализации прав и свобод личности [2, с. 165-166].

Правовой порядок должен охватывать все сферы государственной деятельности: правотворчество, процессы применения правовых норм, судопроизводство, правоохранительные структуры и многие другие области функционирования государственной власти. Общая направленность правового порядка в этих сферах предопределяется верховенством демократической по своей сущности Конституции страны.

Обладая несомненными правовыми ценностями, Конституция призвана обусловливать наличие правовой законности в практическом функционировании правового порядка. Это конструирует гарантии того, что действующий правовой порядок не будет входить в противодействие с устремлениями гражданского общества и его членов.

Правовой порядок по своей природе и сущности признает приоритет права как ценностного общественного явления и верховенство закона, отдавая приоритет правовому закону. На такой мощной основе функционирования правового порядка члены общества получают реальные возможности добиваться своих жизненных целей и приоритетов. 
Правовой порядок - сложная функционирующая система, которая впитывает в себя не только ценности права, но и начала принципов нравственности, справедливости, политической целесообразности, социального рационализма, культурно-эстетической меры, которые отражают поведенческие акции членов общества в процессе их многообразной жизнедеятельности.

Правовой порядок не может проявлять себя и быть существенной реальностью вне социального и правового поведения членов общества. Правовой порядок - это сфера жизнедеятельности каждого человека, при соприкосновении его с определенной правовой действительностью, правовыми жизненными обстоятельствами, когда необходимо делать тот или иной юридический ход.

Анализ практических сторон правового порядка позволяет судить о том, в какой степени идеи, принципы, ценности, нормы права нашли воплощение в соответствующем функционировании государственных и муниципальных органов, деятельности должностных лиц, повседневном бытии членов общества. Положительные итоги такого анализа позволяют исходить из вывода, что правовой порядок в соотношении с правовой законностью выступает в качестве той стержневой основы, которая обусловливает развитие институтов гражданского общества и структур правового государства - благодатной среды, позволяющей личности обретать начала своего достойного жизненного существования.

Сущность правового порядка заключается в том, чтобы инициировать функционирование правовой государственности и институтов и учреждений гражданского общества на началах ценностей права и правовых законов, отстаивания приоритетных интересов, потребностей, прав и свобод каждой личности, испытывающей постоянную потребность в своем достойном существовании.

Поэтому опора правового порядка исключительно на компоненты позитивного (действующего) права, без привлечения потенциала правовых законов, представляет собой своего рода отказ от правовых ценностей. Это ослабляет позиции и потенциальные возможности правового порядка, снижает его эффективность и практическую результативность и тем самым отдаляет каждого человека от достижения определенных жизненных устремлений.

Вне связи с правовыми законами правовой порядок утрачивает свои определенные ценностные качества, перестает быть надежным гарантирующим средством, позволяющим личности активно и целеустремленно достигать необходимых жизненных целей, избегать ненужных социальных и юридических издержек. В определенной мере утрачивается и правовой ореол необходимого порядка в соответствующих жизненных обстоятельствах. Одновременно подрываются основы уважения права как ценностного общественного явления, ослабляется вера в правовые возможности, которые воспринимались ведущим компонентом многих сторон жизнедеятельности членов общества.

Поэтому следует особо подчеркнуть, что правовой порядок становится полноценным, является фундаментом функционирования гражданского общества и правового государства, жизненной опорой большинства членов общества при условии его ставки на внедряемые в общественные отношения правовые законы.

Правовой порядок как особое ценностное и практическое состояние общественной и частной жизни аккумулирует свой эффективный потенциал посредством правовых законов, которые несут в себе ценности права и трансформируют их в жизнедеятельность людей.

Правовые законы соотносятся и в определенной мере отождествляются с правовым порядком в силу того, что адресованы каждому члену общества в целях создания предпосылок для реализации соответствующих личностных интересов, потребностей, прав и свобод. Такая ценностно-целевая направленность правовых законов воспринимается значительной частью членов общества и гарантирует им мотивацию и осуществление непременно правомерного поведения, что надежно конструирует и сам правовой порядок, придает ему ценностную истинность, реальность.

Только в условиях развивающегося гражданского общества правовые законы имеют возможность обретать всеобщую и общеобязательную силу, занимать позиции действительного верховенства в системе права. Такая сущность правовых законов не может не восприниматься сущностью и потребностями диктуемого обществом надежного правового порядка. На базе правовых законов инициируется и внедряется в жизнь развивающегося гражданского общества именно тот правовой порядок, который соответствует воле и жизненным интересам боль- 
шинства членов данного общества, является ведущим фактором обеспечения достойного существования человека.

Постепенное, но целенаправленное внедрение ценностей права в сферы правового порядка призвано предъявлять повышенные требования не только к членам общества как массовым субъектам права, но и ко всем государственновластным структурам и должностным лицам. При этом должна преследоваться кардинальная миссия - искоренить или свести к минимуму проявления произвола, беззакония, бюрократизма, волокиты, подкупа, коррупции.

При достижении успехов в указанных сферах социальной и правовой действительности возникают дополнительные возможности для укрепления самого правового порядка. В итоге этого правовой порядок обретает четкую тенденцию всестороннего содействия все тем процессам, которые ведут к устойчивой реализации жизненно важных интересов и потребностей большинства членов гражданского общества.

Достижение значимых и постоянно необходимых жизненных рубежей может протекать только на основе осознанного предсказуемого и массового правомерного поведения. Только в рамках правомерных акций достижима реализация прав и свобод одних членов общества без посягательства на права и свободы других членов общества. Именно массовое и исключительно правомерное поведение членов общества становится основополагающей закономерностью правового порядка, отдающего предпочтение правовым ценностям и другим ценностям социума.

Именно истинный правовой порядок инициирует тот правовой микроклимат, который позволяет каждой личности как субъекту права мотивировать и осуществлять правомерное поведение как единственно верный и надежный способ достижения тех жизненных результатов, которые исключены вне использования правовых средств и возможностей. Любые противоправные акции подрывают основы правового порядка, отторгают ценности права из этой сферы, ухудшают жизненное положение членов общества.

Воспринимаемый обществом и его членами порядок обретает свойства правового только при наличии действительного демократического режима, становления надежных основ гражданского общества и правовой государственности, восприятия идей и принципов естественного права и других правовых ценностей, внедрения в действующую систему права правовых законов, признания личности, ее прав и свобод высшей социальной ценностью.

Правовым является такой порядок, который стабильно нормализует жизнедеятельность и общества, и его членов, благоприятно сказывается на функционировании государственновластных структур, эффективно противодействует преступности в стране, всякого рода противоправным акциям и, в конечном счете, содействует упорядочению общественных отношений на началах справедливости, гуманизма, нравственности и других значимых принципов и ценностей.

Только такой правовой порядок способен укреплять и развивать политический, социальный, правовой и иной статус человека, контролировать и обусловливать должным образом правовые предпочтения, намерения, склонности человека с тем, чтобы удержать его в параметрах мотивации и осуществления непременно правомерного поведения.

Только инициируемый легитимными, обоснованными, рациональными интересами личности, общества, государства правовой порядок может стать естественной, необходимой, практически значимой потребностью социальной и правовой действительности, ареной воплощения истинных правовых ценностей.

Однако движение к этому правовому идеалу - дело сложное, неоднозначное, долговременное, требующее огромных усилий всех заинтересованных политических, социальных, общественных структур и граждан, способных преодолевать многочисленные препятствия и решать кардинальные проблемы. Поэтому термин «правовой порядок» пока воспринимается как идеальная данность, а в действительности является «правопорядком» - явлением, производным от действующей системы права, правовой жизни общества [3, сс. 164-168].

Однако стремление именно к правовому порядку как основе нормального течения общественных отношений остается притягательной и перспективной тенденцией. Ведь субъекты права в своем подавляющем большинстве не только не уклоняются, а напротив, заинтересованы в таком порядке, который бы в определенной мере гарантировал достижение многих жизненных целей, а не тормозил их достижение. Каждо- 
му человеку необходим такой порядок, основанный на ценностях права, который бы позволял удовлетворять приоритетные интересы и потребности и предоставлять каждой свободной личности возможность успешно добиваться реализации любых жизненных намерений, которые адекватны правовым дозволениям.

Естественное стремление каждого человека в условиях демократизации общественной жизни и становления основ гражданского общества находиться в среде представляющих интерес прав и свобод органически вводит его как субъекта права в многогранный мир правовых ценностей. Практически это означает, что действующая система права, призвана отражать идеи и принципы естественного права, раскрывать свой богатый и мощный регулятивный и охранительный потенциал в тех сферах жизнедеятельности членов общества, где открываются для каждой личности новые возможности для качественного преобразования своего социального и правового статуса, продвижения к основам достойного существования.

Основанный на такой базе правовой порядок дает человеку возможность свободно проявлять свою волю во всех значимых сферах жизнедеятельности и тем самым формировать себя в качестве творческой, инициативной личности, самостоятельно добивающейся реализации поставленных жизненных целей. Залогом таких возможностей становится опора на соответствующие правовые ценности, которые внедряются в действующий правовой порядок и придают ему необходимую динамику и эффективность.

\section{Библиографический список}

1. Черданцев А. Ф. Теория государства и права. Учебник.-Москва, 2001.

2. Христин Р.Д. Отдельные аспекты деятельности государства в сфере укрепления правового порядка // Теория государства и права. Москва, 2020. Сс. 165-169.

3. Рожкова А.К. Правовая реальность и правовой идеал: точки соприкосновения // Известия Иркутской государственной экономической академии. Иркутск. 2010. № 6. Сс. 164-168. 